\title{
Article \\ Challenging Gender and Disability Stereotypes: Narrative Identities of Brazilian Female Paralympians
}

\author{
Lyusyena Kirakosyan (D)
}

Virginia Tech Institute for Policy and Governance, Blacksburg, VA 24061, USA; lyusyena@vt.edu

\begin{abstract}
The purpose of this narrative inquiry is two-fold: first, to illuminate the views and experiences of Brazilian female Paralympians that helped shape their narrative identities, and second, to develop a better understanding of the reasons behind the gender inequality in Paralympic sports. According to the International Paralympic Committee, 1671 female athletes competed in the Rio 2016 Paralympics, representing almost 40 percent of the participating Paralympians. In Rio, Brazil had the largest Paralympic delegation in its history, with 287 Paralympians, of which only 102 were women (about 35 percent). The reasons why there is a significant discrepancy between male and female Paralympic participation are highly complex and little researched, particularly in Latin American contexts. In examining the complexities of these women's narrative identities and their relationship with social norms, I draw on the insights from disability feminism, identity theory, and disability sport to analyze and interpret the Paralympic sportswomen's narrative accounts. Individual interviews with 20 Brazilian female Paralympians from nine different sports revealed the intricate relationships each has with social norms regarding gender, disability, sport, and the body.
\end{abstract}

Keywords: narrative identity; gender; disability; stigma; social norms; Paralympic sport

check for updates

Citation: Kirakosyan, L. Challenging Gender and Disability Stereotypes: Narrative Identities of Brazilian Female Paralympians. Disabilities 2021, 1, 420-437. https://doi.org/ 10.3390/disabilities1040029

Received: 4 September 2021 Accepted: 1 November 2021 Published: 4 November 2021

Publisher's Note: MDPI stays neutral with regard to jurisdictional claims in published maps and institutional affiliations.

Copyright: (C) 2021 by the author. Licensee MDPI, Basel, Switzerland. This article is an open access article distributed under the terms and conditions of the Creative Commons Attribution (CC BY) license (https:// creativecommons.org/licenses/by/ $4.0 /)$.

\section{Introduction}

Fewer women than men participate in disability sport, and the reasons behind such inequity are complex. There is insufficient research that examines the specific causes of this situation and particular difficulties women face in their access to sport [1-3]. The gender gap in disability sport participation also exists in Latin America, with little scholarly research on this issue [4]. Scholars point to many factors that contribute to the lack of representation of women in disability sport. Gendered relations of power, social and cultural barriers, and belief systems, as well as women's personal choices, might impact their sport participation and even hinder efforts to increase awareness of the issues unique to the disabled female athlete [2,5]. The interviews that I have carried out indicate that some of the biggest problems relate to the lack of awareness about resources, poverty, insufficient support, lack of adequate transport, and accessible facilities. But many women are simply not interested in sport in the first place.

This narrative inquiry has two main purposes: first, to comprehend the experiences of Brazilian female Paralympians that shaped the different dimensions of their narrative identities; and second, to develop a better understanding of the reasons behind the gender inequality in Paralympic sport in Brazil. Empirical research on disability sport in Brazil and Latin America is limited [6]. Therefore, in this study, I specifically focused on the experiences of the Brazilian female Paralympians to bring visibility to their experiences and issues and address a lack of research attention to the intersection of gender, disability, and sport in this context [3].

This article provides a space for the voices and stories of disabled sportswomen whose personal narratives highlight how they navigate the social norms and their own experiences of inequality, impairment, discrimination, and sporting achievements while striving for the agency in constructing their identities. Drawing on Hargreaves, who affirmed that personal 
experience is fundamental to understanding disabled women [2], I conducted individual interviews with 20 female Paralympians who participated in the Rio 2016 Paralympics (out of 102 female participants). Their stories produced a sense of who these women are and what their daily lives are like, alongside their struggles, hopes, and aspirations.

\subsection{Research Context}

Scholars noted that Paralympic sport had enhanced perceptions of disabled people and their accomplishments inside and outside of sport [7-10]. However, serious inequities continue to exist for women both within Paralympic sport as well as in its comparison with Olympic sport. Participant numbers have traditionally been uneven, and in the Rio 2016 Paralympic Games, out of the total 4238 participants, only 1671 were female Paralympians [11], or about 40 percent. Similarly, in the Rio Olympic Games, out of a total of 11,238 participants, only about 45 percent were women. In 2016, Brazil had its largest Paralympic delegation in history, with 287 parathletes, of which 102 were women [12], or about 35 percent. Brazil's Olympic delegation totaled 465 athletes, with 209 women [13].

Although gender inequity was identified in previous work within the able-bodied sports world, the domain of disability sport has its particularities. Olenik and her colleagues argued that generalizing from the barriers and experiences in the able-bodied sport to disability sport downplays the significance of women's experiences within this setting by ignoring the historical and political context of their experiences [14]. Women with impairments aspiring to elite sporting competitions often face double discrimination associated with disability and gender, compounded by systemic gendered barriers related to participating in a male-dominated sports arena [14]. As Anderson claimed, "society still perceives sport, a social construct, as an able-bodied male domain" [15] (p. 427). Although social change has been taking place in recent decades in women's participation in sports, it has been uneven and limited by what Messner called "soft essentialism", which is a system of shared beliefs that conveys "the unevenness of social change in sports" [16] (p. 16).

In Latin America, gender inequality persists despite the broader representation of women in the social, political, and cultural domains. The same gender stereotypes of the feminine role and the resulting prejudice and discrimination that undermined women's achievements in societies worldwide have been at work in the region. Similarly, while women's sports participation has also been growing across Latin America, there is still extensive evidence of significant inequalities between men and women as professional athletes, coaches, referees, and administrators [17]. Women's sport is still relatively invisible, and women are radically underrepresented in sports leadership at every level [18]. These inequalities are even more evident in disability sport. For instance, in the Lima 2019 Pan American Games, out of 6452 participating athletes, 46\% were women [19], while in the Para Pan American Games, out of 1837 participating parathletes, only 33\% were women [20].

The trajectory of Brazilian women in sport reflects what was happening to them in other social settings. Rubio and her colleagues have pointed out how slow and inconsistent the advances of Brazilian women have been in the domains of work, education, sports, and politics [21]. Initially, in the 1930s, only a handful of sportswomen were allowed to compete in the Olympics, and only in the individual sports, which intended to reflect the Brazilian women's personal rather than collective efforts. From 1941 to 1979, several governmental decrees and resolutions prohibited Brazilian women from practicing sports as it was seen as incompatible with their perceived feminine nature.

From 1980 onwards, the practice of sports by women in Brazil has gradually expanded. Brazil sent its first women's team to compete in the 1980 Moscow Olympics in volleyball. Brazilian sportswomen won the first medals in the Atlanta 1996 Olympics, and since then, they have become indispensable for the nation's medals ranking. However, although the Olympic achievements showed that Brazilian sportswomen had become more successful than men, they still accounted for less than half of the delegation [21]. 
Research shows that access to sport in Brazil has long been marked by gender inequalities, where sport participation among girls is lower than among boys [21,22]. Deeply seated beliefs in some parts of Brazilian society have considered girls' and women's sport participation as potentially antithetical to their femininity and endangering what has been considered the destiny of all women - wife and motherhood [21].

\subsection{Research Questions}

I sought to design the research questions to capture the views and experiences of the female Paralympians and structured my effort to be informed by their struggles and to contribute to academic and practical knowledge. Foregrounding these women's unique individual experiences can help generate resistance to the dominant narratives they encounter in everyday interactions and recognize people's embodied experiences as part of a broader understanding of disability [23].

The central research questions framing this study are:

- How did the direct experiences of sportswomen's gender and disability shape their identities in Paralympic sport?

- How did the sportswomen's personal experiences and narratives clash with the existing social norms regarding gender, sport, disability, and the body?

These questions address the critique raised by other researchers about disability sport, largely failing to examine the personal stories of the representatives of this group and to address their unique realities and perspectives [23,24]. Indeed, efforts to analyze and locate events in the individuals' life stories can help identify a basis for identity and action and contribute to forming and strengthening a collective identity [25].

\section{Conceptual Framework}

I chose to combine three bodies of literature in a framework that first helps situate the study's aims and second, provides a theoretical lens to analyze and interpret the narrative accounts and experiences. I drew on the insights from disability feminism, identity theory, and disability sport to frame the discussion of the sportswomen's views and experiences in Paralympic sport and in broader social contexts that shaped the different aspects of their narrative identities.

\subsection{Disability Feminism}

Several scholars working in disability feminism justified the need for this niche within the academic enterprise of gender studies because disability rights have not been addressed by mainstream feminism [2,26-30]. Disability feminism "incorporates the interactions between gender and disability, combines the personal with the social, and sets the sense of the body against institutional, cultural and political structures" [2] (p. 193). The challenge for disability feminism is to find ways to not only support the particular position of disabled women but also acknowledge the differences and complexities of their experiences [2,29-31].

As Wendell rightly pointed out, feminists have been grappling with issues that disabled people face in a different context:

- Whether to stress sameness or difference in relation to the dominant group and in relation to each other;

- Whether to place a higher value on independence from the help of other people, as the dominant culture does or to question a value system which distrusts and devalues dependence on other people and vulnerability, in general;

- Whether to pursue the goal of full integration into male-dominated/able-bodied society, seeking equal power with men/non-disabled people in that society, or whether to preserve some degree of separate culture, in which the abilities, knowledge and values of women/disabled people are particularly honored and developed [30] (p. 105).

Sheldon noted that examining the links between feminist and disability rights movements points to ways in which they can learn from and strengthen each other [29]. Be- 
cause disabled women struggle with both kinds of oppressions, of being women in maledominated societies and being disabled in ableist societies, they are in a unique position to share their insights and experiences of disability into feminism and feminist perspectives into the disability rights movement and scholarship [30,31]. Although disabled people have recognized that feminism can offer much to disability studies, non-disabled feminists have not often considered the contribution of disabled women to feminist thought and at times even endorsed viewpoints that were damaging to both disabled women and men [29].

The understanding of disability as a matter of power relations is at the center of disability feminism. How a society conceptualizes disability and whom it recognizes as disabled has vast implications for both people experiencing themselves as disabled and those who are not but are nevertheless labeled as such [30,32]. Garland-Thomson, a feminist disability scholar, explained that "disability, like femaleness, is not a natural state of corporeal inferiority, inadequacy, excess, or a stroke of misfortune. Rather, disability is a culturally fabricated narrative of the body, similar to what we understand as the fictions of race and gender. The disability/ability system produces subjects by differentiating and marking bodies" [26] (p. 5). In her view, reinterpreting disability involves both working toward ending disability discrimination and offering a rationale that allows people to claim disability identity without seeing it as a diminishment of the self [27].

\subsection{Identity and Narrative}

Identity is our understanding of ourselves and of other people, and, in turn, other people's understanding of themselves and others, including us [33]. An individual's identity is always multidimensional and sociocultural in its origins; it is not fixed and immutable, but instead, it is negotiable and flexible [33]. In this context, because disability undermines the cultural belief about the body as the unchanging anchor of identity, it advances the notion of "the essential dynamism of identity" and highlights "the fluidity of all identity" [26] (p. 20).

Anderson distinguished between a personal identity that, in her view, is concerned with an individual's core characteristics, and a social identity, which she defined as identification with others based on specific group characteristics [15]. Unlike Anderson, Collins viewed the self (and, therefore, personal identity) as a social construction that emerged in social interaction [34]. Claiming identities for ourselves and ascribing particular identities to others is closely linked to exercising power [35]. Consequently, both gender and disability impact the formation of personal identity and intertwine in ways individuals are included in or excluded from society [25].

The narrative provides for a dynamic process of identity formation and ensures that the voice of participants is adequately heard [34]. Narrative identity refers to an individual's autobiographical past and their projections of the future in a way that creates a coherent account of identity in time with a degree of "unity, purpose and meaning" [36] (p. 233). The sociocultural model of narrative identity suggests that it builds slowly over time through repeated interactions with others, as people process, edit, reinterpret, and retell their stories about personal experiences $[36,37]$. Over time, this process results in a gradual development of a broader and more integrative narrative identity. The essential quality of narratives is not in their facticity but the role they play in the process of identity creation and transformation [37]. Because the narrative is created by the experience and at the same time it shapes the experience, Collins considered narrative and self to be inseparable [34].

Socialization is a crucial determining factor in identity development $[15,38]$. In the context of sport, family members and coaches become influential figures in the development of the sports identity of children at an early age, shaping children's social learning experiences through gender-typing of sports and participation in sport itself [15]. Furthermore, as Hardin suggested, many of the attitudes, beliefs, and self-identities of disabled athletes relate to the way they internalize ideology about gender and disability prevalent in society [1], circling back to the issues of power raised by scholars earlier [25,35]. 


\subsection{Disability Sport and Gender}

The study of sport, in general, has stimulated substantial interest among scholars from diverse disciplines, among them sociologists, historians, economists, and political scientists. Still, such an interest in disability sport and its issues has been far slower to develop and arguably remains significantly weaker [39]. Although disability sport has been a rapidly growing cultural phenomenon in the last decades, it has received little attention from the mainstream sports media and disability rights activists [35,40]. Disability sport has issues of unequal representation and is usually administered and led primarily by non-disabled men $[1,41]$. The lack of administrative and coaching positions filled by disabled people undermines both men and women with impairments. Moreover, insufficient acknowledgment of the actual experience of disability results in both male and female parathletes experiencing a lack of control over decisions that affect their athletic careers [2]. If sports organizations were controlled and administered by disabled people themselves, they would be in a better position to spot and challenge biases and promote equality and anti-discriminatory practices [2].

As several scholars have observed (e.g., [23,42]), organized sport, including disability sport, has served as a powerful cultural domain to perpetuate the ideology of male superiority and dominance through maintaining social order and gender segregation. Mainstream feminism failed to challenge the values inherent in the dominant model of competitive sport [2] (p. 4): by not questioning sport's global relations of power and underlying values that produce present-day sports heroes and heroines, feminism indirectly supports the creation of "commodified and glamorized heroines of sport", a criticism that also applies to disability sport. Disability sport would greatly benefit from a feminist political presence, as such feminist debates could help shed light on its gendered character and the fact that the majority of people in the positions of power are men [2]. Such lack of representation of women as athletes, administrators, and coaches in disability sport continuously hampered efforts to increase awareness of the issues unique to the female athlete with impairments [14].

Huang suggested that disabled sportswomen, in comparison to their male peers, face more social and cultural barriers that in turn obstruct their sporting opportunities and often discourage them from pursuing athletic careers [43]. Olenik et al.'s research found that sportswomen's families or communities may not consider the practice of disability sport as a "normal" sport [14]. In this case, participation in disability sport may reinforce an image of being "different" or "disabled" and pose challenges associated with sustaining sports participation. When disabled women gained sports opportunities, they often chose between livelihood and sport, especially in the early stages. Weak support systems for female athletes exacerbate financial, time, and cultural constraints often experienced by disabled women who have little institutional or interpersonal backing in general [14].

In an effort to address the low representation of women as athletes, coaches, officials, and leaders, the International Paralympic Committee (IPC) established the Women in Sport Commission in 2003 to better understand barriers that limit their participation at all levels of Paralympic sport and to recommend policies and initiatives that address these barriers [44]. These steps have contributed to an increase in the female Paralympians' participation numbers in the subsequent Games editions, but gender equity is not yet a reality in this domain.

This study aims to contribute to the literature on disability feminism, narrative identity, and disability sport in the following ways. First, because research investigating the influence of sport on disabled athletes' sense of self and identity development is limited [45], the present analysis of their multiple identities and roles in which they find meaning helps fill this gap. Moreover, there have been no studies that addressed the specific Latin American social and cultural contexts in which the identities of the Paralympic athletes have developed. Second, my analysis contributes to what Hargreaves calls "feminism of disability sport" [2] (p. 193). In her critical evaluation, disability feminists paid little attention to sport, and sport feminists paid little attention to disability, resulting in no 
articulated feminism of disability sport. Moreover, according to Remi and colleagues, there is a lack of studies addressing the issues of gender identity of disabled sportswomen [46]. By drawing on the broader cultural narratives about gender and disability, I offer a better understanding of the reasons behind gender inequality in Paralympic sports. Third, this study also contributes to a broader discussion about power and social inclusion/exclusion issues by examining the intersection of gender, disability, and sport. I hope to stimulate a debate within research on disability sport, feminism, and disability studies about how these diverse voices and stories can be highlighted to address inequality within Paralympic sport and society at large.

\section{Research Design and Methods}

The research design encompasses approaches to inquiry, data collection strategies, and strategies for data analysis selected to conduct a study [47]. As a narrative inquiry, the study placed people, their lived experiences, and personal identities at the center, inviting the development of interpretive methodologies, since "when people tell stories, they interpret and give meaning to the experiences depicted in their stories. The act of telling is always a performance, a process of interpretation and communication in which the teller and listener collaborate in sense-making" [48] (p. 202).

\subsection{Study Participants}

Before this study, I had not personally met the interviewees but had seen some of them on TV during the Rio Paralympics. The Paralympians I interviewed had visual and physical impairments and different times for onset of impairment: few of them had congenital conditions, while the majority acquired visual or physical impairments later in life. Their age ranged between 18 and 45. Ten of the interviewees practiced team sports (sitting volleyball—nine, and goalball—one), and the remaining ten practiced individual sports (Paralympic judo-two, athletics—three, swimming —one, wheelchair fencingone, shooting sports—one, powerlifting-one, and table tennis-one). For a third of the interviewees, Rio Paralympics was the first sporting mega-event in their lives. At the same time, two-thirds of them competed in the previous editions of the Summer Paralympic Games.

\subsection{Data Collection}

In October 2016, I reached out to the Paralympic Academy of the Brazilian Paralympic Committee, requesting their assistance in contacting Paralympians for the interviews. The Academy asked for the study description, aims, instruments, and my researcher credentials for the internal analysis and approved the study in January 2017. Subsequently, the Academy gave me access to the coaches of Paralympic sports, who served as my points of contact with the sportswomen. Some coaches shared all active athletes' emails and phone numbers, while others chose who I could talk to and directed me to those athletes. I contacted the athletes, presented the study aims, and requested an interview. Upon an agreement to an interview, I emailed them the consent form that they signed and returned before we spoke.

Participant interviews served as my primary source of data. Focus areas of the interviews and sample questions within each included the following: (a) self-perceptions of the body and one's capabilities, (b) history of involvement in a sport before and after the onset of impairment, (c) gender, impairment, and sport-related stereotypes and experiences, (d) motivation for sports participation and its importance in one's life, (e) experience in the Rio 2016 Paralympics and personal significance of participating, and (f) take on the media's portrayal of the Paralympics, participating athletes and disabled people in general. The interviews were guided by open-ended exploratory questions, through which I sought to engage with diverse perspectives, encouraging respondents to offer their own definitions and meanings of their experiences. 
The conversations took place in Portuguese in the period between March and June 2017. Because the interviewees were spread across Brazil, I used different media of interviewing: in person, over the phone, voice calls, or chats on Skype or WhatsApp, at times convenient to the participants. I met some interviewees in person in São Paulo, while others from more distant locations were contacted by phone, voice calls, or chats. Each interview lasted between $40 \mathrm{~min}$ to an hour. I recorded the interviews with the athletes' consent, transcribed them myself, analyzed them in Portuguese, then translated the selected passages into English. The process of contacting the participants, interviewing, transcribing, and analyzing the data took place over the same period. With their permission, I refer to the sportswomen I interviewed by their first names to address the issue of anonymity and the hypervisibility of disability that Peers claimed often surrounds their identities and accomplishments [24].

I followed the constructionist conception of interviewing [49], where the meanings were co-constructed by the interviewee and the researcher during the interview. I also followed a receptive interviewing practice [50], which enabled the interviewees to exercise significant control over how they answered the questions. Not only did every interview provide a unique story of life, struggle, and achievement, but it also helped to shed light on different dimensions of their identities.

\subsection{Data Analysis and Interpretation}

Bochner and Riggs contended that analysts of the narrative "retell stories by way of their analyses and thus express what the stories mean in an analytic, often abstract, form" [48] (p. 202). These scholars also suggested that analysts would need to show how the data-analytic strategies respect and maintain not only the integrity and coherence of the stories but also the context in which they were told. The text that is prepared for analysis results from decisions by a researcher about what he/she will examine and in what ways it will be interpreted and contextualized [48].

After transcribing and organizing the interview texts, I compiled and closely read the material several times for a general idea of the participants' accounts. Subsequently, I undertook a more detailed analysis of the interviews with a coding process, using a combination of predetermined (those based on the reviewed literature) and emerging codes (those that arose from the interviews themselves). The coding process helped generate themes, and subsequent thematic analysis enabled me to observe and discern patterns within data to construct meanings that led to a more interpretive understanding of different aspects of identity.

Predetermined codes were rooted in the reviewed literature: for example, gender stereotypes and expectations (from family and peers); female beauty narratives (in society and the media); victim/superhero identity (in sport and other contexts). Emerging codes arose from the interviews: for example, the centrality of sport to self-identity (not imagining themselves away from sport); personal meanings of disability (accomplishments thanks to impairment, impairment as a lifetime opportunity; and gendered hierarchy and insufficient recognition in Paralympic sport (underrepresentation, less recognition, and access). Both predetermined and emerging types of codes helped develop and refine the analytical ideas, generating themes later grouped into identity categories. For example, "Gender stereotypes and expectations", "Female body/beauty narratives", and "Gender inequality and discrimination" were grouped under the "Gender identity" category. I became empirically confident about reaching the saturation point when no additional codes or further insights emerged from the data analysis.

\section{Discussion of Identities}

This section is organized into three parts: gender identity, disability identity, and athletic identity. Because these identities are closely intertwined in the interviewees' narratives, it was difficult to isolate a specific aspect of identity for analysis. The primary goal here is to analyze and interpret the firsthand narrative accounts about the views 
and experiences of female Paralympians, underscoring the multiplicity and complexity of identity categories.

\subsection{Gender Identity}

The notion of women's biological frailty and inferiority is used extensively to justify the male hegemony in sport [43]. The belief that certain sports masculinize female participants has kept many women away from such sports as powerlifting, shooting sports, fencing, and rugby, among others [43]. Malhotra and Rowe explained that when grappling with the dual expectations of the female gender role and the "disabled" role, women, differently from men, face a distinct challenge [25]. Both roles have traditionally anticipated similar qualities of physical helplessness and passivity, resulting in a perception of disabled women as dependent. However, for men, the combined gender and disability identities work differently: as the anticipated qualities of masculinity and having an impairment are in nearly direct opposition, men may choose to reject the expectations inherent in the "disabled" role by more fully embracing the male gender role [25]. In other words, as Gerschick summed it up, "having a disability erodes much, but not all, masculine privilege" [28] (p. 1265).

My analysis of the sportswomen's narratives about their gender identity identified three interconnected themes: gender stereotypes and expectations, female body/beauty narratives, and gender inequality and discrimination.

\subsubsection{Gender Stereotypes and Expectations}

Although women in Brazilian society are gaining more acceptance for taking part in conventionally masculine sports, they still suffer, to some extent, from "cultural tensions between athleticism and femininity" [51] (p. 349). These pressures are managed through social control or strong encouragement for women athletes to emphasize their feminine features [51]. Several of the interviewees commented on the persistent gender stereotypes enacted by their families and peers:

Nowadays, my father accepts it. But in the past, when I just started practicing judo, as I stepped on the tatami mat, sweated, and got bruised, he would be horrified and say, "It's not for you; you are a girl". Many thought judo was not for women because of physicality and vanity. But it was before; today, people are more accepting. (Lucia, Paralympic judo)

Shooting is a male-dominated sport, and I have always felt that. It was not explicit, but I always felt that I had to prove that I was better, that I was capable of achieving more. I felt this pressure because I am a woman. When I win in a mixed competition [with male and female participants competing together], men usually make fun of the one who loses, 'wow, shame on you, you lost to a woman!' I think it exists in the Olympic sport too; they will always prefer a male athlete. (Debora, shooting)

These statements suggest that these women have a different understanding of women's "acceptable" gender roles because they are among the top elite athletes in Brazil's Paralympic sport. In Latin American societies, the stereotypes of the feminine role of girls and women remain widely shared, and those involved in sport and risk challenging these stereotypes still may face prejudice and discrimination [3].

Garland-Thomson has argued that such stereotypical narratives may ultimately reinforce exclusionary environments, employment discrimination, and social marginalization [27]. Consequently, women with impairments have been stereotypically regarded in the collective cultural imagination as "inferior, lacking, excessive, incapable, unfit and useless" [27] (p. 1567). To combat these stereotypes, many women who perform in traditionally male domains focus on improving "the self" and holding themselves to higher standards, as the quotes above illustrated. 


\subsubsection{Female Body/Beauty Narratives}

The body plays a crucial role in hegemonic gender ideals, where masculinity is linked to concepts of physical strength and fitness, and femininity is grounded in physical attractiveness [25]. Recently, disabled sportswomen have successfully transformed their physical bodies, previously characterized as defective and pathological, into bodies that reflect athletic ability and empowerment [2]. However, as Garland-Thomson observed, existing cultural stereotypes view disabled women as unattractive and incompatible with the ideals of womanhood and feminine beauty [26]. This notion was expressed by one of my interviewees in the following passage:

One incident that upset me took place in 2015. I was on TV receiving a Paralympic award, and soon after, I received a text message on my cell phone from a modeling agency. They invited me to a photoshoot, and there were many other girls there too. When I was about to take a profile picture from the side where I have hand impairment, the photographer asked me to turn [to the other side]. I refused and said I would take the pictures the same way as other girls did. So, he took the photos. Sometime later, the agency called me and said that I was too old for them [she was 25 at the time] and that they could not promote me. But I was sure it was because of my impairment, and I was shocked. (Suellen, sitting volleyball)

Another sportswoman mentioned a video clip published by Brazil's largest media company in honor of International Women's Day in March 2016, a few months before the Rio Paralympics. A 30-second clip featured three non-disabled Olympic sportswomen and claimed to celebrate "the victories, achievements, and overcoming [of challenges] of all of Brazil's women" [52]. It ended with the phrase "We are all Olympic", which not only excluded the Paralympic sportswomen but also millions of women with impairments as if they were not women to be celebrated. Yet another similar example was a 2016 campaign launched by Vogue Brasil with an intention to draw public attention to the upcoming Paralympics. The campaign featured two young non-disabled Brazilian actors, one male and one female, whose images were altered to simulate impairments (arm and leg amputations, more specifically) instead of showcasing real-life disabled individuals or Paralympians [53].

Both the video clip and the Vogue Brasil's campaign were missed opportunities to not only showcase what Hargreaves called "heroic images of disabled sportswomen for popular consumption" but also move from exclusion and invisibility of millions of disabled women to their greater inclusion and visibility [2] (p. 199). Although this small number of elite Paralympic sports stars do not authentically represent all disabled women, they may serve as symbols of an imagined community and group pride and help transform the stereotypes of disabled women as weak and passive victims [2].

\subsubsection{Gender Inequality and Discrimination}

Research shows that gender stereotypes may lead to gender discrimination [54], which in turn can negatively impact women's sporting progression. In the interviews, some sportswomen downplayed the presence of gender inequalities and stated they had not experienced any related difficulties but indicated an awareness of persisting disparities and discrimination. Le Clair explained that to compete, Paralympic athletes need a particular frame of mind with a positive "can-do" attitude and reject the negativity that discrimination represents [9]. As one visually impaired athleticist noted,

I have never suffered from prejudice because of my visual impairment or being a woman in Paralympic sport. I think it is because I never allowed others to treat me with pity. Because of my attitude, people treat me as a "normal" person; I do not leave room for prejudice (Lorena, athletics).

The statement features notions of personal agency and self-exploration as Lorena carefully negotiates her gender and disability identities to enjoy, as McAdams and McLean put it, "successful adaptation to life" [36] (p. 236). However, Seal considered such stories 
of success problematic in the context of parasport [23]. They raise, in her view, unrealistic expectations of what athletes should achieve and perpetuate. In this case, the idea of "overcoming" disability and gender barriers propagates the notion of individual responsibility and downplays the complexities associated with discriminatory experiences. She further argued that the narratives that position the individual as the one who attempts to conform to "able-bodied" and gendered practices result in removing any responsibility from the institutions and society and place too much onus on the individual to "fit in", as articulated in the quote below:

The discrimination starts from the edge of the pool. In Rio, we had more women participating in the Games, but there are generally fewer spots for us. I experienced discrimination in sports for being a woman. There is also a joke that women train less than men, so people scream, "Ah, you're training like a little girl, like Edenia. Go train with her since you are not training hard". It often goes unnoticed, but it is machismo. There is another factor: it is still challenging to find female coaches. Our technical committee is all male, except for our doctor (Edenia, swimming).

A significant under-representation of women in parasport, both as athletes, coaches, and other professionals, is another expression of gender inequality that hinders raising awareness about many concerns unique to this group $[2,14,41,55]$.

Several sportswomen also commented on the inequalities in the media coverage of the male and female sports, referring to the coverage during the Rio Paralympics.

We had 8000 people at the gymnasium watching our bronze medal game. So, to say that people were not curious, that they did not want to see us play, would be a lie. There were lots of people cheering for us. But our medal-winning game was not even televised in Brazil (Gisele, sitting volleyball).

The media tends to produce more coverage of disabled sportsmen than disabled sportswomen, and some sports and impairments are prioritized over the others, which elite sportswomen view as demeaning [2]. Sports media are part of a network of power relations that serve primarily to reinforce the existing gender order [40,52]. Knijnik and Soares de Souza's analysis of the coverage by one of Brazil's most essential and progressive newspapers revealed that women were "invisible" in sports media and continued experiencing prejudice and discrimination in the 21st century [56]. Thus, sports media coverage contributes to reinforcing the traditionally unfair views of female sport and determines the availability of female sports role models and possibilities to challenge existing attitudes [40].

\subsection{Disability Identity}

Notions of impairment and disability informed my interviewees' understanding of self and how they negotiated disability identity in relation to their other identities. As Seal pointed out, focusing on disabled women's individual experiences can help generate resistance to the prevailing disability narratives they encounter on the "micro" level and recognize people's embodied experiences as part of a more comprehensive understanding of disability [23]. I identified three related themes in their narratives: personal meanings of disability, the stigma associated with impairment and disability, and the victim/superhero identity.

\subsubsection{Personal Meanings of Disability}

When referring to their disability identity, all my interviewees de-emphasized physical limitations and rejected the expectations of helplessness and dependency. Even though the participants dismisseded the label of being disabled as a way of self-identification, it did not mean that their identities were not partly shaped by their impairment.

Sometimes the solution is in the impairment itself. Had I not had it, I would not have accomplished everything I did. The majority of the athletes acquired their impairments later in life, and I see that they are much happier after becoming impaired. It may sound 
strange. Visiting Rio was my childhood dream, and now I live here. I was able to buy a house for myself and my mother (Marivana, athletics).

Impairment for me was an opportunity to meet other people, to see the world, to become an athlete. I have never thought I would become an athlete, especially not an elite athlete. It has been an opportunity for me, and I am making the most of it (Jani, sitting volleyball).

After I entered the sport, I began seeng myself differently. I suffered from prejudice before, did not accept myself as I was. After getting into the sport, my life has changed. I never imagined being where I am today. In a short time, I went to the Paralympics. My social interactions changed, and I see myself in a different light today (Mariana, weightlifting).

These statements imply that these elite disabled athletes view disability differently. The meaning they attributed to their impairments rejected the tragic view of disability that is evocative of loss. Instead, they recognized how the challenges and opportunities they had in life impacted how they see the world. Although these women are considered "disabled" athletes for the official classification purposes of Paralympic sport, they did not see themselves as limited or lacking in any sense or think of themselves as disabled. As they prioritize their sporting abilities, for them, the experience of impairment is located in the "sporting body", which is "competent and empowering" [2] (p. 203) or, as Hardin put it, they are "able-disabled" [1] (p. 50). Their positive self-conception does not match the prevailing negative conception of disability in society [57].

\subsubsection{Disability Stigma}

The female Paralympians frequently cope with disability stigma and with being perceived as the weaker sex. Together, these identities reinforce the negative perceptions contained in each [35]. Drawing on previous research, Le Clair noted that the development of disability identity occurs in the context of three mechanisms of discrimination-individual, structural, and internalized, i.e., discrimination that operates through the stigmatized person's beliefs and behaviors [9]. Charlton explained that society's negative beliefs and attitudes toward impairment and disability are eventually internalized by individuals with impairments themselves, making it difficult to find a starting point to challenge and transform those beliefs and attitudes [58]. As the following quotes illustrate, these women rejected the limiting disability label through their sports participation and accepted their bodies and their "difference".

Today, I do not experience stigma as much. But when I just came to train from Natal [capital of the Rio Grande do Norte state], before the Athens 2004 Paralympics, I faced a lot of prejudice because of my accent, my physical shape. Once I was denied an interview because of that. I prefer to think that the person who chose not to interview me was the one who missed out because I have a lot to contribute. Just because I am imperfect by their physical standards does not mean I am devalued (Edenia, swimming).

In my perception, there is more prejudice against people like me, whose impairment is not so visible. I see people preferring to sponsor someone whose impairment is more evident. People in Brazil think that only those who use wheelchairs or miss a limb make up the disabled population. In people's minds, if the impairment is not visible, then it does not exist. People focus on what is missing in a person, and if apparently nothing is missing, then you are a regular person (Marivana, athletics).

The excerpts above articulate the internal fundamental change of the disability stigma that these sportswomen achieved, which was empowering to them. In Le Clair's terms, "the symbol of inequity is turned on its head. It is also part of the transformative process of self-identifying and the structural redefinition from being a person with a disability to that of a high-performance [athlete] with a disability" [9] (p. 1126). 


\subsubsection{Victim/Superhero Identity}

While the Paralympians do not rely on the heroism narrative per se, they approach their story as one about seeking out and overcoming challenges. The theme of overcoming and the related portrayal of parathletes as superheroes was one of the main topics that emerged from the interviews. Some participants embraced the narrative of overcoming and saw it as one of the central features of the Paralympic sport, pushing them to rise over the difficulties and barriers they faced and establish new records and win medals. Others were more careful with the narrative of overcoming not taking over their sporting achievements. But all participants were unanimous in rejecting the superhero label, as their accounts below express. They viewed the superhero label linked to their impairments that undervalued their athletic accomplishments. The sportswomen distanced themselves from the victim or limiting view of disability identity, which in turn highlighted the apparent inconsistency between the disability label and the abilities the athletes demonstrate in sport [9].

A victim and a superhero are two extremes; we just want to be ourselves. [...] Every athlete is potentially a superhero because we do extraordinary things. But it is not because of our impairment that we are superheroes; it is because we overcame it. It is the overcoming of an athlete, pushing the boundaries of possible as high-performance athletes. We do not want to be victims because we are capable. But we are also not superheroes just because we have physical limitations and are capable of doing something (Lucia, Paralympic judo).

The Paralympic athlete is closely linked to overcoming; it is not real. If you have an impairment, it does not mean you are limited; you adapt to live that way. But you are excellent in your sport, you are an athlete, and the impairment moves into the background. You will need adaptations to train, but it does not mean you will train less than an Olympic athlete. [...] The Paralympic athlete should not be encapsulated in this one wordovercoming - we have many other qualities and achievements (Marivana, athletics).

I am against the Paralympic "heroism". It is not what we should sell. But it is what sells best, overcoming and heroism, which perpetuates prejudice in Brazil (Edenia, swimming).

In sport and beyond, disabled individuals are often expected to overcome obstacles to participation by their own extraordinary efforts, or their families are expected to provide what they need, which frequently comes at great personal sacrifice [30]. The idea of "overcoming" disability contributes to two distorted perceptions about disability: first, it perpetuates the idea that disability is an individual matter; and second, it generates the impression that someone with an impairment needs merely to apply a heroic effort to overcome existing barriers in life [23]. Such perceptions imply that the responsibility for success is placed on the individuals themselves, without considering all the other factors that impact their success [59].

Hargreaves also pointed to a strong bias in the media that foregrounds impairment and underrates sporting skills and achievements: "elite sportswomen are constructed less frequently as sporting heroines and more usually as disabled sportswomen" (emphasis in the original) [2] (p. 199). This may have been one of the reasons that Brazil's Paralympic sportswomen were not featured in that commemorative video for International Women's Day, as they did not fit the Olympic ideal of sporting heroines.

\subsection{Athletic Identity}

The diverse elements of the women's athletic identity, from their entry into the sport and their sporting achievements to how the notion of elite athlete intersects with gender and disability-related experiences, demonstrated the complex ways they talk about themselves. Athletic identity refers to the extent to which individuals identify with the role of an athlete [45]. Athletic identity allows the Paralympians to become role models with the capacity to empower the broader population with impairments [60]. I identified three 
interrelated themes linked to these women's athletic identity: impact of sport, the centrality of sport to self-identity, and insufficient recognition of Paralympic sport and parathletes.

\subsubsection{Impact of Sport}

For all my interviewees, becoming involved in sport was a turning point in their lives. Sport participation allowed them to "better" their lives and the lives of their loved ones, impacting their self-worth and their identity.

Sport means everything to me. It is my life. It gave me the strength to deal with my impairment [She was already practicing judo when she was diagnosed with Stargardt's disease at the age of 14 that left her blind] and pursue my goals. Sport is fundamental to my life (Alana, Paralympic judo).

I am fulfilled through sport today. It brought me freedom and independence. I was very dependent on others. It made me see the world differently. It impacted my social life and dramatically improved my self-esteem (Suelen, wheelchair fencing).

I have been playing sports my whole life; I cannot imagine myself without it. I accomplished some things besides the medals. Thanks to sport, I earned my higher education degree, and today I teach physical education in the municipal schools (Suellen, sitting volleyball).

These excerpts show how these women benefited from their involvement in sport and built-up self-esteem, confidence, and self-efficacy, as outlined in previous studies [2,8,61,62]. In terms of self-esteem, most of the participants described sport as a life-changing experience that brought them many intrinsic and extrinsic benefits and an enhanced view of their own capabilities. Moreover, sport participation raised questions about what constitutes a disabled body [8].

\subsubsection{The Centrality of Sport to Self-Identity}

Narratives about gender and impairment did not give the Paralympians a sense of who they are as much as the narratives about sporting achievement, goals, and motivation. Paralympic sport has been an essential part of these women's identities and lives and the most valued activity performed with pride and a sense of fulfillment, primarily when representing Brazil at the Paralympics in Rio.

[After being away from judo for some time], when I put on the kimono again, I felt in that moment that it was what I had been missing. It was a unique moment. Putting on kimono and stepping on the tatami mat felt like, "how could I be away for so long?" It felt like I returned home, you know? It is a singular sensation that judo brings up in me. I tried swimming, goalball, but judo is the only sport that is incredibly fulfilling to me (Lucia, Paralympic judo).

I do not see myself away from the sport. Today, I run a nonprofit in Natal [capital of the Rio Grande do Norte state] with my friends, and we develop outreach programs in partnership with the Federal University. These programs target children with impairments. [ ... I I am thinking of building a sports institution that will help promote children and adolescents to the national level. I do not see myself away from the movement (Edenia, swimming).

Many women spoke about the joy and passion they found in sport and how they could not imagine themselves without this practice. Few other women chose to advocate for disability sport across the nation.

As a whole, the sense of deep fulfillment, self-empowerment, and the feeling of belonging expressed by these sportswomen underscored the importance of inclusive and accepting environments, where people with impairments can experience themselves as a whole, an adequate person rather than an individual defined by their disability [62]. By resisting social stigma around physical performance and appearance, disabled athletes can experience empowerment by their sporting achievements and physical capabilities $[8,60]$. However, 
there are still many practices and policies in disability sport that reproduce ableism and gender bias within the sport system and can be excluding to the athletes $[2,23,43]$.

\subsubsection{Gendered Hierarchy and Insufficient Recognition in Paralympic Sport}

All of my interviewees commented on the little acknowledgment of parasport and parathletes in Brazil. According to Marques and Gutierrez, Paralympic sport in Brazil is not consolidated enough to create the demand for visibility and recognition [63].

As their statements below imply, female Paralympians continue experiencing less visibility and recognition in the Brazilian elite sport. Hargreaves' conclusion that "disabled sportswomen lack power in their relations with able-bodied women, with disabled men, with the media, and with disability sports officials" articulates the essence of the position of sportswomen in elite disability sport [2] (p. 204). The quotes below illustrate these challenges related to a gendered hierarchy of Paralympic sport:

I have had competitions canceled because there are not enough women in goalball. Brazil has more male than female goalball teams. We end up missing opportunities because women's participation in sport is low. Some of the issues behind this are barriers to women's access to sport, and blind women are seen as more vulnerable. They do not go out much, engage less in sport, and are overprotected by their families (Simone, goalball).

We do not have enough female teams in São Paulo, and so we play with men. We compete as equals and beat them. There is a lack of female teams in São Paulo and across Brazil; there are only five-six teams (Gisele, sitting volleyball).

Indeed, the recruitment of female Paralympians remains a significant challenge in many world regions, including Brazil. At an elite level, in comparison to the Olympic Games, the proportion of Brazil's female athlete participation in the Paralympic Games lagged by approximately 10 percent, and Blauwet attributed it to a lack of access to sport rather than an insufficient number of potential participants [55].

The Brazilian female Paralympians won more medals in Rio than their Olympic peers. Still, they did not receive the same attention in the media or the same acclaim in popular consciousness as the achievements of non-disabled sportswomen did.

I believe that Paralympic athletes want more recognition. There is not enough recognition of the Paralympic sport. Our female sitting volleyball team won a medal in the Rio Paralympics. We were the first female team in Brazil to win a medal [in the Paralympics], but we were not acknowledged (Adria, sitting volleyball).

Our medal was the first in the female collective sport, but it did not bring us any return in terms of media exposure, sponsorship, or marketing. I feel that collective sport is less recognized than an individual sport. In volleyball, 12 athletes win one medal, but one athlete can win 3-4 medals in athletics or swimming. This recognition is also different when it comes to sponsorships (Camila, sitting volleyball).

These narratives articulate what Hargreaves called the hope of "being mainstreamed", bringing disabled sportswomen "equal access to sports resources, equal funding and equal representation on decision-making bodies" [2] (p. 213). She further argued that "'being mainstreamed' should acknowledge equality as a right, not a privilege. Part of that right would be the continuance of disability sports organizations to ensure equality for those disabled sportswomen whose needs are best met through those channels" [2] (p. 213).

\subsection{Research Limitations and Future Directions}

This study has a delimited scope in terms of a specific period, geographic location, and targeted group of participants. Additionally to this scope delimitation, I discuss two limitations that impact the study's findings: sample profile and financial constraints. First, the study analyzed the narratives of Brazilian female Paralympians who competed in the Rio 2016 Games. Including the narratives of retired female Paralympians could have revealed different or additional identity features and contributed to a more robust 
understanding of the complexities of gender inequality within and outside sport. Second, financial constraints impacted both the duration and geographic reach of the study. The interviews were conducted shortly after the Rio Paralympics and greatly reflected the realities of that cycle. Extending the research duration and collecting data throughout the subsequent Paralympic cycles (Tokyo 2020 and beyond) can yield new insights into the sportswomen's narrative accounts. Furthermore, the possibility to travel with and observe these women in the competitive and other social contexts in Brazil or abroad could contribute to a better understanding of their identity development and the importance of different identity features in different contexts.

Researchers express fundamental concerns about a reliable generalization from a small sample in qualitative studies or a single case study, considering it a significant limitation. When discussing the potential for generalizations from the implications of a small-scale study, it has been suggested that the analysis considers two aspects of generalization: first, if the findings can be transferable to other contexts, and second, if generalizations can be made within the case study [64]. In terms of the first aspect, the findings in this study are supported by the existing international literature and are potentially transferable to other national contexts in developing and developed nations. The scholars commented on the cultural tensions between athleticism and femininity and how the media serve primarily to reinforce the existing gender order [2,51], the rejection of limiting disability label through sport and stereotypes about the feminine body $[1,2,9,23,30]$, and how practicing sport impacted acceptance of disability identity and resulting empowerment $[1,2,8,9,59,60]$. While different contexts can shape specific aspects of personal stories differently and thus impact the recognition and validation of a given identity in light of others, the overarching narrative is that through sport, many female Paralympians could access opportunities, acquire status, and develop skills to lead a fulfilling life and reframe their disability identity in more affirmative terms. With regard to the second aspect of generalization, the insights from this study may contribute to debates about feminism and gender equality both within and beyond sport in Brazil, such as, for example, ways to enhance recognition and appreciation in sport, the media's role in challenging gender stereotypes, addressing barriers for women with impairments in sport and wider society among others.

The analysis of disabled sportswomen's identity construction can be deepened by further research that addresses a more sizeable sample of interviewees that may target retired and active Paralympians, their coaches, psychologists, physiotherapists, national Paralympic Committee leadership, and other stakeholders. Their additional perspectives and experiences may help contribute to the debate on the personal and collective identity construction within Paralympic sport and outline paths to greater equality within the Paralympic movement in Brazil and elsewhere. Future research could also explore in greater depth possible differences within the population of women with impairments while considering the intersection of gender, disability, and sport. For example, patterns may vary by type of disability, congenital versus acquired disabilities, or time living with a disability. Moreover, subgroups within the population of women with impairments (e.g., race, ethnicity, age, social class, sexual orientation, educational background) could introduce additional belief systems that further complicate the dynamics in the Latin American sport context. Taken as a whole, these factors should assist in furthering our understanding of a group of women that has rarely been the focus of scholarly research.

\section{Conclusions}

This article drew on the voices and stories of disabled sportswomen whose narratives revealed the complex interaction between gender, disability, and athletic identities in the context of Paralympic sport.

In answer to the first research question about how the direct experiences of sportswomen's gender and disability shaped their identities in Paralympic sport, the analysis of their narratives highlighted that while some participants were careful with the narrative of overcoming not taking over their sporting achievements, others seemed to have embraced it and saw 
it as one of the central features of the Paralympic sport, pushing them to establish new records and win medals. However, all participants unanimously rejected both the victim/limiting view of disability identity and the superhero label that they saw linked to their impairments that undervalued their sporting performance. Moreover, the sportswomen seemed to have internalized the individual responsibility for "overcoming" disability and gender barriers, as they focused their efforts on improving "the self" and holding themselves to higher standards, which results in downplaying the complexities associated with discriminatory experiences. Gender inequality in Paralympic sport is also expressed in a significant under-representation of women in parasport, as athletes, coaches, and administrators, which hinders the efforts to raise awareness about many concerns unique to this group. Furthermore, several sportswomen also commented on the inequalities in the media coverage of male and female sports, referring to the coverage during the Rio Paralympics, which supported the arguments made in the existing literature. Thus, biased sports media coverage reinforces the traditionally unfair positioning of female sport and possibilities to challenge existing attitudes.

The second insight concerns how the sportswomen's personal experiences and narratives clashed with the existing social norms regarding gender, sport, disability, and the body. A common thread running through the discussion of the multiple identities was a narrative of independence and empowerment. As these women showcased their capabilities and actively challenged disability and gender stereotypes, they claimed their identity agency, which clashed with the dominant social norms regarding gendered and impaired bodies in sport. Through their gender production strategies, disabled sportswomen had to perform "masculinity" to gain legitimacy in the male-dominated realm of sport by showing how tough and independent they were. At the same time, disabled sportswomen had to perform femininity that not only resisted stigmas but also confronted the image of an "unattractive" athlete. Additionally, the increasing visibility of these sportswomen helps to move beyond the notion of the impaired body as a burden [2], which may inspire other disabled women to pursue sporting opportunities.

However, the female Paralympians' narratives have not always been coherent and consistent. While individual sportswomen affirmed that they experienced an increased sense of personal empowerment through their sporting achievements and physical abilities, Hardin pointed out that they still operate within "the institution of sport [that] continues to disenfranchise them" [1] (p. 51). These issues came to light in some interviews in the narratives of insufficient recognition and visibility, promotion of superhero identity, gender and disability-based discrimination, and individual responsibility that together place the burden to achieve and maintain such empowered athletic identities upon disabled people.

Funding: This research received no external funding.

Institutional Review Board Statement: The study was approved on 19 July 2016, by the Virginia Tech Institutional Review Board, protocol 16-667.

Informed Consent Statement: Informed consent was obtained from all subjects involved in the study.

Acknowledgments: I am grateful to the Brazilian Paralympic Academy for giving me access to the coaches of Paralympic sports, who served as my contact points with sportswomen. I am also grateful to Max Stephenson, Jr. for his continuous support and comments on previous drafts of this paper.

Conflicts of Interest: The author declares no conflict of interest.

\section{References}

1. Hardin, M. 'I consider myself an empowered woman': The interaction of sport, gender and disability in the lives of wheelchair basketball players. Women Sport Phys. Act. J. 2007, 16, 39-52. [CrossRef]

2. Hargreaves, J. Heroines of Sport: The Politics of Difference and Identity; Routledge: Abingdon, UK, 2000.

3. D'Amico, R.L.; Benn, T. Latin America: An introduction. In Women and Sport in Latin America; D'Amico, R.L., Benn, T., Pfister, G., Eds.; Routledge: Abington, UK; New York, NY, USA, 2016; pp. 3-17.

4. Soláns, A.P. Historias de vida de deportistas paralímpicas. trayectorias biográficas. Apunt. Educ. Física Y Deportes 2014, 3, 84-90. [CrossRef]

5. D'Amico, R.L.; Benn, T.; Pfister, G. (Eds.) Women and Sport in Latin America; Routledge: Abington, UK; New York, NY, USA, 2016. 
6. Cottingham, M.; Blais, D.; Gearity, B.; Bogle, K.; Zapalac, R. A qualitative examination of Latin American wheelchair sport practitioner's marketing practices. J. Sport Dev. 2015, 3, 8-19.

7. Jefferies, P.; Gallagher, P.; Dunne, S. The Paralympic athlete: A systematic review of the psychosocial literature. Prosthet. Orthot. Int. 2012, 36, 278-289. [CrossRef]

8. Kavanagh, E. Affirmation through disability: One athlete's personal journey to the London Paralympic Games. Perspect. Public Health 2012, 132, 68-74. [CrossRef] [PubMed]

9. Le Clair, J.M. Transformed identity: From disabled person to global Paralympian. Sport Soc. 2011, 14, 1116-1130. [CrossRef]

10. Swartz, L.; Bantjes, J.; Rall, D.; Ferreira, S.; Blauwet, C.; Derman, W. A more equitable society: The politics of global fairness in Paralympic Sport. PLoS ONE 2016, 11, e0167481. [CrossRef] [PubMed]

11. International Paralympic Committee (IPC). Rio de Janeiro 2016. Available online: https://www.paralympic.org/rio-2016 (accessed on 31 August 2021).

12. O Dia. Cerimônia no Maracanã dá Início aos Jogos Paralímpicos. Available online: https://odia.ig.com.br/_conteudo/esporte/ olimpiada/2016-09-06/ cerimonia-no-maracana-da-inicio-aos-jogos-paralimpicos.html (accessed on 31 August 2021).

13. Comitê Olímpico Brasileiro (COB). Time Brasil Para o Rio 2016. Available online: https:/ / www.cob.org.br/pt/time-brasil/vagaspara-rio-2016 (accessed on 31 August 2021).

14. Olenik, L.M.; Matthews, J.M.; Steadward, R.D. Women, disability and sport: Unheard voices. Can. Woman Stud. 1995, 15, 54-65.

15. Anderson, D. Adolescent girls' involvement in disability sport: Implications for identity development. J. Sport Soc. Issues 2009, 33, 427-449. [CrossRef]

16. Messner, M.A. Gender ideologies, youth sports, and the production of soft essentialism. In No Slam Dunk: Gender, Sport and the Unevenness of Social Change; Cooky, C.M., Messner, A., Eds.; Rutgers University Press: New Brunswick, NJ, USA, 2018; pp. 15-36.

17. Benn, T.; de D'Amico, R.L. Conclusion. In Women and Sport in Latin America; D'Amico, R.L., Benn, T., Pfister, G., Eds.; Routledge: Abington, UK; New York, NY, USA, 2016; pp. 226-234.

18. Pfister, G. Gender, gender equality and women's sport: Theories and practices. In Women and Sport in Latin America; D'Amico, R.L., Benn, T., Pfister, G., Eds.; Routledge: Abington, UK; New York, NY, USA, 2016; pp. 32-54.

19. Lima 2019. Women's Noteworthy Participation in Pan American Games. Press Release. 2019. Available online: https://www. lima2019.pe/en/news/womens-noteworthy-participation-in-pan-american-games (accessed on 31 August 2021).

20. Redacción Lima 2019. Legado de Los Juegos Realizó Exhibición-Taller de Hockey de Mujeres en el Marco de la Campaña "Iguales en la Vida, Iguales en el Deporte". 2020. Available online: https:/ /www.lima2019.pe/noticias/legado-juegos-realizoexhibicion-taller-hockey-mujeres-marco-campana-iguales-vida-iguales-deporte (accessed on 31 August 2021).

21. Rubio, K.; Altmann, H.; Mourão, L.; Goellner, S.V. Women and sport in Brazil. In Women and Sport in Latin America; D’Amico, R.L., Benn, T., Pfister, G., Eds.; Routledge: Abington, UK; New York, NY, USA, 2016; pp. 69-78.

22. Mariano, M.; Altmann, H. Educação Física na Educação Infantil: Educando Crianças ou Meninos e Meninas? Cad. Pagu 2016, 46, 411-438. Available online: https://periodicos.sbu.unicamp.br/ojs/index.php/cadpagu/article/view/8645916 (accessed on 31 August 2021). [CrossRef]

23. Seal, E.L. Juggling Identities: Elite Female Athletes' Negotiation of Identities in Disability Sport. Ph.D. Thesis, University of Bath, Bath, UK, 2014.

24. Peers, D. (Dis)empowering Paralympic histories: Absent athletes and disabling discourses. Disabil. Soc. 2009, 24, 653-665. [CrossRef]

25. Malhotra, R.; Rowe, M. Exploring Disability Identity and Disability Rights through Narratives: Finding a Voice of Their Own; Routledge: Abingdon, UK, 2014.

26. Garland-Thomson, R. Integrating disability, transforming feminist theory. NWSA J. 2002, 14, 1-32. [CrossRef]

27. Garland-Thomson, R. Feminist disability studies. Signs 2005, 30, 1557-1587. [CrossRef]

28. Gerschick, T.J. Toward a theory of disability and gender. Signs 2000, 25, 1263-1268. [CrossRef]

29. Sheldon, A. Personal and perplexing: Feminist disability politics evaluated. Disabil. Soc. 1999, 14, 643-657. [CrossRef]

30. Wendell, S. Toward a feminist theory of disability. Hypatia 1989, 4, 104-124. [CrossRef]

31. Bernardini, M.G. Taking disability seriously: On the feminist disability studies critic to the mainstream feminism. Periódico Do Núcleo De Estud. E Pesqui. Sobre Gênero E Direito 2015, 2, 148-164. [CrossRef]

32. Campbell, F.K. Contours of Ableism: The Production of Disability and Abledness; Palgrave Macmillan: London, UK, 2009.

33. Jenkins, R. Social Identity, 4th ed.; Routledge: New York, NY, USA, 2014.

34. Collins, P. Storying self and others: The construction of narrative identity. J. Lang. Politics 2003, 2, 243-264. [CrossRef]

35. Huang, C.-J.; Brittain, I. Negotiating identities through disability sport. Sociol. Sport J. 2006, 23, 352-375. [CrossRef]

36. McAdams, D.P.; McLean, K.C. Narrative identity. Curr. Dir. Psychol. Sci. 2013, 22, 233-238. [CrossRef]

37. Engel, D.M.; Munger, F.W. Narrative, disability, and identity. Narrative 2007, 15, 85-94. [CrossRef]

38. Adams, G.R.; Marshall, S.K. A developmental social psychology of identity: Understanding the person-in-context. J. Adolesc. 1996, 19, 429-442. [CrossRef] [PubMed]

39. Thomas, N.; Smith, A. Disability, Sport and Society: An Introduction; Routledge: London, UK, 2009.

40. Meier, M. The value of female sporting role models. Sport Soc. 2015, 18, 968-982. [CrossRef]

41. Olenik, L.M. Women in Disability Sport: Multidimensional Perspectives. Ph.D. Thesis, University of Alberta, Edmonton, AB, Canada, 1998. 
42. Cooky, C.; Messner, M.A. (Eds.) No Slam Dunk: Gender, Sport and the Unevenness of Social Change; Rutgers University Press: New Brunswick, NY, USA, 2018.

43. Huang, C.-J. Discourses of Disability Sport: Experiences of Elite Male and Female Athletes in Britain and Taiwan. Ph.D. Thesis, Brunel University, Uxbridge, UK, 2005.

44. Hums, M.A. Women with disabilities in sport. In Women and Sport: Continuing a Journey of Liberation and Celebration; Staurowsky, E.J., Ed.; Human Kinetics: Champaign, IL, USA, 2016; pp. 147-161.

45. Pack, S.; Kelly, S.; Arvinen-Barrow, M. 'I think I became a swimmer rather than just someone with a disability swimming up and down:' Paralympic athlete's perceptions of self and identity development. Disabil. Rehabil. 2017, 39, 2063-2070. [CrossRef] [PubMed]

46. Remi, R.; Joncheray, H.; Dugas, E. Disabled sportswomen and gender construction in powerchair football. Int. Rev. Sociol. Sport 2017, 52, 61-81. [CrossRef]

47. Levitt, H.M.; Bamberg, M.; Creswell, J.W.; Frost, D.M.; Josselson, R.; Suárez-Orozco, C. Journal article reporting standards for qualitative primary, qualitative meta-analytic, and mixed methods research in psychology: The APA Publications and Communications Board task force report. Am. Psychol. 2018, 73, 26-46. [CrossRef] [PubMed]

48. Bochner, A.; Riggs, N.A. Practicing Narrative Inquiry. In The Oxford Handbook of Qualitative Research; Leavy, P., Ed.; Oxford UP: New York, NY, USA, 2014; pp. 195-222.

49. Brickmann, S. Unstructured and Semi-Structured Interviewing. In The Oxford Handbook of Qualitative Research; Leavy, P., Ed.; Oxford UP: New York, NY, USA, 2014; pp. 277-299.

50. Wengraf, T. Qualitative Research Interviewing; Sage: Thousand Oaks, CA, USA, 2001.

51. Dworkin, S.L.; Messner, M.A. Gender relations in sport. Sociol. Perspect. 2002, 45, 347-352. [CrossRef]

52. Globo. Dia da Mulher: Somos Todas Olímpicas. Video Clip. 2016. Available online: https://www.youtube.com/watch?v= KFaKsVEumao (accessed on 31 August 2021).

53. Campanha Que Simula Deficiência em Famosos Cria Polêmica Nas Redes Sociais. A Critica. Available online: https://www. acritica.com/channels/entretenimento/news/campanha-que-simula-deficiencia-em-famosos-cria-polemica-nas-redes (accessed on 31 August 2021).

54. Bobbitt-Zeher, D. Gender discrimination at work: Connecting gender stereotypes, institutional policies, and gender composition of workplace. Gend. Soc. 2011, 25, 764-786. [CrossRef]

55. Blauwet, C.A. The Paralympic female athlete. In The Female Athlete; Mountjoy, M., Ed.; Wiley: Hoboken, NJ, USA, $2015 ;$ pp. 120-127.

56. Knijnik, J.D.; Soares de Souza, J.S. Brazilian women in the sports press: A case study. J. Hum. Sport Exerc. 2011, 6, 12-26. [CrossRef]

57. Barnes, E. The Minority Body: A Theory of Disability; Oxford UP: Oxford, UK, 2016.

58. Charlton, J.I. Nothing about Us without Us: Disability Oppression and Empowerment; University of California Press: Berkeley, CA, USA, 1998.

59. Silva, C.F.; Howe, P.D. The (in)validity of supercrip representation of Paralympian athletes. J. Sport Soc. Issues 2012, 36, 174-194. [CrossRef]

60. Purdue, D.E.J.; Howe, P.D. See the sport, not the disability: Exploring the Paralympic paradox. Qual. Res. Sport Exerc. Health 2012, 4, 189-205. [CrossRef]

61. Deal, M. Disabled people's attitudes toward other impairment groups: A hierarchy of impairments. Disabil. Soc. 2003, 18, 897-910. [CrossRef]

62. Silverman, A.M.; Cohen, G.L. Stereotypes as stumbling-blocks: How coping with stereotype threat affects life outcomes for people with physical disabilities. Personal. Soc. Psychol. Bull. 2014, 40, 1330-1340. [CrossRef] [PubMed]

63. Marques, R.F.; Gutierrez, G.L. O Esporte Paralímpico No Brasil: Professionalismo, Administração e Classificação de Atletas; Phorte Editora: São Paulo, Brazil, 2014.

64. Tracy, S.J. Qualitative quality: Eight 'big tent' criteria for excellent qualitative research. Qual. Inq. 2010, 16, 837-851. [CrossRef] 